\title{
Arah Penyebaran Stress Coulomb pada Batuan akibat Gempabumi Kairatu 26 September 2019
}

\author{
Harti Umbu Mala ${ }^{* 1}$, Juliany N. Mohamad ${ }^{2}$ \\ ${ }^{1}$ Jurusan Fisika, Universitas Pattimura, Jl. Ir. M. Putuhena, Kota Ambon, Maluku \\ 97233, Indonesia \\ ${ }^{2}$ Program Studi Fisika, Universitas Nusa Cendana, Jl. Adisucipto Penfui Kupang \\ 85001, Indonesia \\ *Penulis Penanggungjawab.E-mail: hartiumbumala@gmail.com (Harti Umbu Mala), \\ Telp: $+62-812-3848-1982$
}

\begin{abstract}
ABSTRAK
Penelitian ini bertujuan untuk mengetahui arah penyebaran stress batuan yang diakibatkan oleh gempabumi Kairatu dan diduga memiliki keterkaitan dengan kejadian gempabumi yang terjadi setelahnya. Penelitin ini menggunakan data kejadian gempabumi yang diperoleh dari katalog United State Geological Survey (USGS) dan Badan Meteorologi, Klimantologi, dan Geofisika (BMKG) pada tanggal 26 September 2019 dan setelahnya. Adapun metode yang digunakan adalah metode perubahan Coulomb stress menggunakan software Coulomb 3.3. Hasil analisis, menunjukkan bahwa gempabumi Kairatu memiliki mekanisme sumber yakni sesar geser sedikit oblige ke arah barat laut, mengalami peningkatan perubahan stress batuan positif yang dominan ke empat arah yakni utara, timur, selatan dan barat dengan kisaran harga $0,4-1,0$ bar. Kondisi dengan nilai perubahan stress yang tinggi ini, sangat berpotensi membangkitkan gempabumi susulan dengan kedalaman hiposenter berkisar $\leq 70 \mathrm{~km}$.
\end{abstract}

Kata Kunci : Gempabumi; Perubahan Stress Coulomb; Kairatu. 


\begin{abstract}
This research aims to study the direction of the coulomb stress change caused by the Kairatu earthquake and its influence with earthquake events that occur afterwards. This research uses earthquake event data obtained from the catalog of the United State Geological Survey (USGS) and Badan Meteorologi, Klimantologi dan Geofisika (BMKG) on September 26, 2019. The method used is the Stress Coulomb Change using Coulomb 3.3 software. The results of the analysis, showed that the Kairatu earthquake had a sourceof focal mechanism is shear fault oblige to northwestward. It has increasing positive stress changes that dominant to the north, east, south and west directions with the range $0.4-1.0$ bar. This conditions that have high stress changes are very make possible to triggering earthquake after the main earthquake occurred with the hypocenter $\leq 70 \mathrm{~km}$.
\end{abstract}

Keywords: Earthquake; Coulomb Stress Change; Kairatu.

\section{Pendahuluan}

Kepulauan Maluku merupakan wilayah dengan tingkat kegempabumian yang tinggi. BMKG mencatat bahwa setiap tahunnya daerah ini selalu diguncang lebih dari 1.000 kejadian gempabumi. Sepanjang tahun 2018 tercatat sebanyak lebih kurang 1.587 kejadian gempabumi mengguncang wilayah ini. Jumlah ini meningkat dibanding tahun sebelumnya tahun 2017 yang hanya terdapat sekitar 1.397 kejadian gempabumi. Kondisi ini disebabkan letaknya yang dihimpit oleh tiga lempeng tektonik utama dunia yaitu lempeng Pasifik, lempeng Australia dan lempeng Eurasia.

Pada tanggal 26 September 2019, warga kepulauan Maluku (Seram, Ambon, Haruku, Saparua) dan sekitarnya dikejutkan dengan kejadian gempabumi yang terjadi di Kairatu, tepatnya pada $3,450^{\circ} \mathrm{LS}$ dan $128,347^{\circ} \mathrm{BT}$, dengan kedalaman sekitar 18,2 km dengan magnitudo moment (Mw) 6,5 [1]. Berdasarkan laporan BMKG per tanggal 4 Oktober 2019, delapan hari pasca gempabumi utama, telah terjadi sekitar 1000 gempabumi susulan [2], dan kondisi ini masih terus berlanjut hingga kondisi batuan yang terdeformasi mengalami posisi stabil.

Munculnya ribuan gempabumi susulan tidak terlepas dari proses penyebaran dan perubahan stress pada batuan yang kemudian terdistribusikan ke segala arah sehingga memberi gangguan pada batuan lain disekitarnya. Ketika batas elastis batuan terlampaui, maka akan 
terjadi pelepasan energi dalam bentuk gempabumi baru akibat batuan sudah tidak mampu lagi menahan stress. Salah satu cara untuk melihat sebaran stress gempabumi adalah dengan melihat dan mengkaji arah perubahan stress Coulomb [3]. Kajian untuk mempelajari dan menghitung perubahan stress Coulomb telah banyak dilakukan oleh para peneliti, antara lain oleh Parsons, dkk [4]; Miao [5]. Mereka mendapatkan bahwa ada keterkaitan antara gempabumi utama dan gempabumi susulan berdasarkan kajian perubahan arah stress coulomb. Sianturi, et al [6] pun pada tahun 2018 mengkaji pengaruh perubahan arah stress coulomb terhadap gempabumi susulan yang terjadi setelahnya di pulau Lombok, dan mendapatkan bahwa gempabumi susulan ini terjadi pada daerah dengann peningkatan stress coulomb berharga positif sekitar $<1,0$ bar. Oleh karena itu dalam artikel ini akan dibahas mengenai pola penyebaran stress batuan akibat gempabumi Kairatu dan pengaruh pelepasan stress gempabumi utama tersebut terhadap gempabumi berikutnya.

Menurut teori keruntuhan Coulomb, ketika dua blok batuan bergeser dengan arah yang berlawanan, maka tegangan geser akan bekerja sejajar dengan bidang sesar. Selain itu, juga bekerja tegangan yang tegak lurus terhadap bidang sesar. Ketika tegangan geser telah melebihi gaya gesek atau ketika tegangan normal berkurang, maka blok batuan akan bergeser secara tiba-tiba dan energi akan dilepas sebagai gempabumi. Kedua komponen tegangan ini apabila dijumlahkan akan diperoleh tegangan Coulomb. Berdasarkan hukum kekekalan energy yang menyatakan bahwa energi yang dilepas tidak akan menghilang, melainkan akan didistribusikan ke segmen sesar lain yang berada disekitarnya dan dapat menyebabkan segmen sesar tersebut patah [7].

Perubahan Coulomb stress juga dapat digunakan untuk mengkaji dan memperhitungkan distribusi stress baik yang sudah terlepas atau yang masih tersimpan pada suatu lempengan atau sesar. Hal ini juga dapat digunakan untuk melihat pola arah pergerakan stress yang sangat membantu dalam memperkirakan arah persebaran gempabumi susulan. Rumusan sederhana sederhana pada Coulomb Failure Stress [3] dinyatakan dengan persamaan:

$$
\sigma_{f}=\tau_{\beta}-\mu\left(\tau_{\beta}-P\right)
$$

$\tau_{\beta}$ menyatakan shear stress paralel terhadap arah slip, $\sigma_{\beta}$ adalah normal stress, $P$ tekanan pori fluida (bar) yang dapat merubah normal stress sepanjang bidang patahan dan dihubungkan dangan koefisien Skeptom (B) dengan nilai bervariasi antara 0 sampai 1 dan $\mu$ koefisien friksi (rentang nilai 0,01 -0,75). Maka, perubahan stress Coulomb statik, $\sigma_{f}$ (Coulomb Failure Function) yang disebabkan oleh sebuah getaran utama dengan asumsi sederhana untuk efek 
tekanan pori menurut Stein, et al. [8] yaitu:

$$
\sigma_{f}=\tau_{\beta}+\mu^{\prime} \sigma_{\beta}
$$

Nilai $\tau_{\beta}$ dalam persamaan ini harus selalu positif, namun proses perhitungan stress pada suatu sesar dapat bernilai positif atau negatif tergantung pada arah slip potensial ke kanan atau ke kiri.

Nilai koefisien gesek semu diasumsikan 0,4 yang merupakan nilai rata-rata. Nilai modulus Young dan rasio Poisson masingmasing diasumsikan $8 \times 10^{5}$ bar dan 0,25 . Selain itu, untuk menghitung nilai perubahan tegangan Coulomb dengan persamaan di atas, maka diasumsikan bahwa tegangan bekerja pada suatu medium elastis setengah bola yang homogen isotropi. Selanjutnya, untuk memperoleh dimensi (panjang dan lebar) rekahan sesar maka digunakan persamaan empiris hubungan magnitudo dan luas bidang sesar yang dikembangkan oleh Wells dan Coppersmith [9]. Sementara itu, konsep kedudukan sesar yang meliputi strike, dip, dan rake mengacu pada konvensi Aki dan Richards [10]. Berdasarkan hasil perhitungan dari persamaan di atas, jika nilai perubahan tegangan Coulomb positif maka potensi untuk terjadi pergeseran akan meningkat dan dapat memicu terjadinya gempabumi susulan didaerah sekitarnya. Sebaliknya, apabila nilai perubahan tegangan Coulomb negatif maka daerah tersebut mengalami relaksasi yang akan mengalami pengurangan tegangan sehingga daerah tersebut dimungkinkan menjadi stabil serta kemungkinan terjadi gempabumi susulan menjadi kecil.

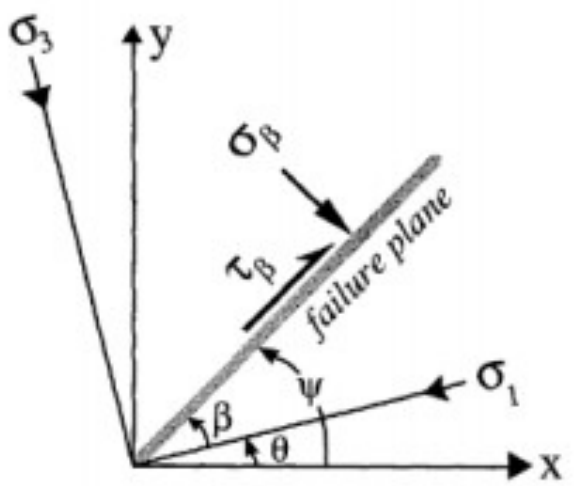

Gambar 1. Sistem koordinat yang digunakan untuk perhitungan Coulomb stress pada bidang sesar optimal [3].

Melalui sistem koordinat sumbu stress pada Gambar 1 ditunjukkan bidang sesar (failure plane) yang dikenakan normal stress $\sigma_{\beta}$. Selanjutnya orientasi bidang sesar dengan sudut $\beta$ membentuk $\sigma_{1}$ sebagai stress utama terbesar dan $\sigma_{3}$ sebagai stress utama terkecil, dengan

$\tau_{\beta}$ adalah shear stress bidang sesar. Kompresi dan shear stress mengarah pada bidang sesar dan berharga positif. Tanda

$\tau_{\beta} \quad$ terbalik dalam perhitungan Coulomb stress untuk sesar geser menganan pada bidang sesar spesifik. Perubahan Coulomb stress dalam bidang sesar optimal dapat dihitung sebagai hasil dari slip sesar utama tempat gempabumi bumi susulan diperkirakan terjadi pada bidang sesar tersebut. 
Perubahan tegangan Coulomb suatu gempabumi utama merupakan parameter yang mampu menjelaskan sebaran gempabumi susulan yang dipicunya [11]. Bahkan, peningkatan stress coulomb mampu menjelaskan terjadinya gempabumi di sepanjang rekahan yang telah terjadi gempabumi. Perubahan tegangan coulomb ini diyakini mengontrol lokasi gempabumi selanjutnya di suatu wilayah. Perubahan tegangan Coulomb tersebut mampu memicu atau bahkan menghambat kejadian suatu gempabumi.

\section{Metode}

Parameter gempabumi berupa posisi diambil dari USGS pada tanggal 26 September 2019 dengan nilai parameter patahan yakni strike $164^{\circ}$, dip $78^{\circ}$ dan rake $-165^{\circ}$ serta divalidasi dengan data pada sumber-sumber lain termasuk data BMKG. Untuk parameter sesar diambil dari hasil perhitungan USGS kemudian dihitung perubahan stress Coulomb dan komponen strainnya. Perhitungan ini dilakukan dengan menggunakan software Coulomb 3.3 Dan menggunakan koefisien friction sebesar 0,4 .

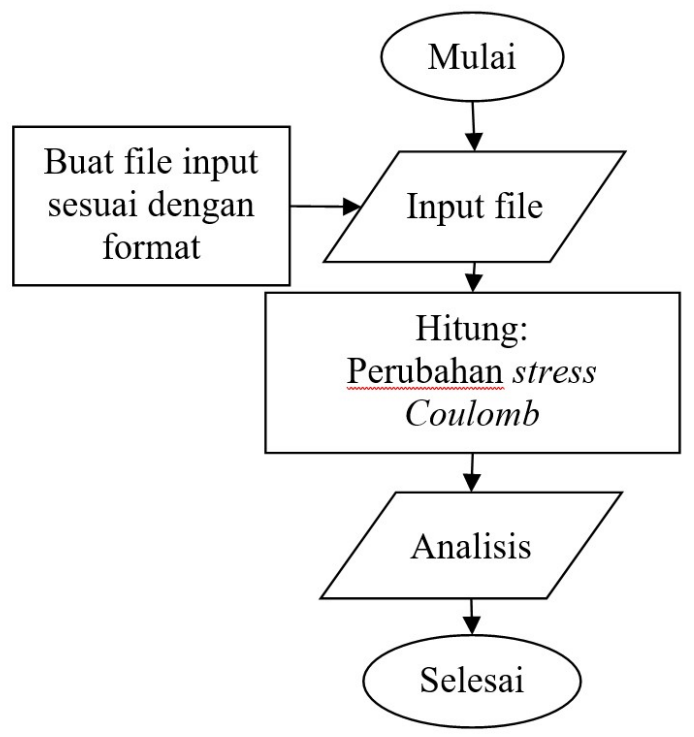

Gambar 2. Alur perhitungan perubahan stress Coulomb dengan Software Coulomb

\section{3}

\section{Hasil dan Diskusi}

Gempabumi Kairatu yang terjadi pada 26 September 2019 dengan Mw 6,5 dibangkitkan oleh sesar geser mengiri atau sinistral strike slip berarah cenderung utara dan sedikit ke arah barat laut seperti yang terlihat pada Gambar 3. Sedangkan perubahan stress batuan menghasilkan pola perubahan (lobus) yaitu pola perubahan peningkatan stress coulomb (lobus) positif berwarna kuning-merah dan pola perubahan stress coulomb (lobus) negatif berwarna biru seperti. Parameter sesar yang digunakan dalam perhitungan yaitu strike $164^{\circ}$, dip $78^{\circ}$ dan rake $-165^{\circ}$. 


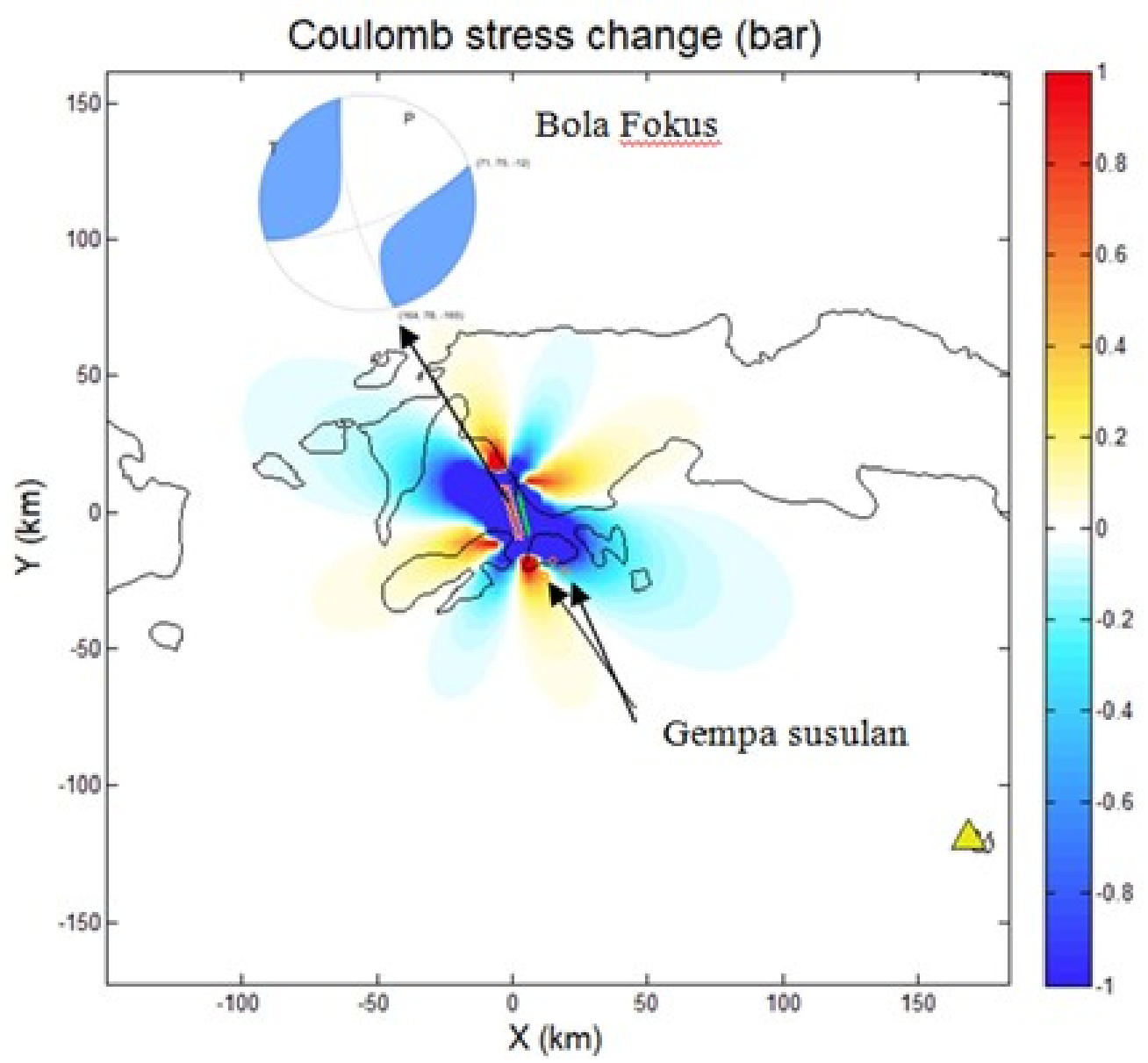

Gambar 3. Mekanisme dan perubahan stress batuan gempabumi Kairatu

Berdasarkan Gambar 3, terlihat bahwa terjadi perubahan stress yang cukup besar dengan perubahan negatif berarah Tenggara - Baratlaut dan Timurlaut -Baratdaya dengan harga sekitar -0,4 sampai -1,0 bar, sedangkan perubahan positif terjadi pada keempat arah yakni Utara, Timur, Selatan dan Barat dengan kisaran harga 0,4 sampai 1,0 bar. Melihat hasil ini, kita mendapatkan gambaran bahwa ada keterkaitan antara gempabumi yang terjadi di Kairatu dengan besarnya perubahan stress Coulomb yang dapat membangkitkan atau mentrigger gempabumi susulan. Daerah dengan perubahan stress coulomb positif cenderung membangkitkan banyak gempabumi susulan, sedangkan daerah dengan stress negatif merupakan daerah relaksasi yang cenderung memberikan kesimbangan pada daerah yang mengalami stress positif. Makin besar nilai stress batuan, maka potensi terjadinya gempabumi susulan makin tinggi dan banyak. Hal ini terkonfirmasi dengan data BMKG yang mencatat lebih dari 2900 gempabumi susulan yang terjadi pasca gempabumi utama Kairatu. 
Untuk melihat lebih jauh pengaruh penyebaran stress batuan secara vertikal, dilakukan cross section seperti tampak pada Gambar 4. Pengambilan penampang melintang A-B dilakukan untuk mengakomodir letak episenter gempabumi utama dan dua gempabumi susulan berikutnya yang terjadi pada waktu yang berdekatan dengan gempabumi utama. Hal ini bertujuan untuk melihat keterkaitan antara gempabumi utama dan gempabumi susulan yang terjadi setelah gempabumi utama terjadi, serta letak gempabumi susulan itu terjadi. Dua gempabumi susulan tersebut adalah gempabumi dengan magnitudo $\mathrm{Mw}$ 4,2 dan kedalaman $10 \mathrm{~km}$, posisi $3,663^{\circ} \mathrm{LS}$ dan $128,455^{\circ} \mathrm{BT}$ serta gempabumi magnitude $\mathrm{Mw}$ 4,7 dan kedalaman $10 \mathrm{~km}$, posisi $3,643^{\circ}$ LS dan $128,523^{\circ} \mathrm{BT}$.
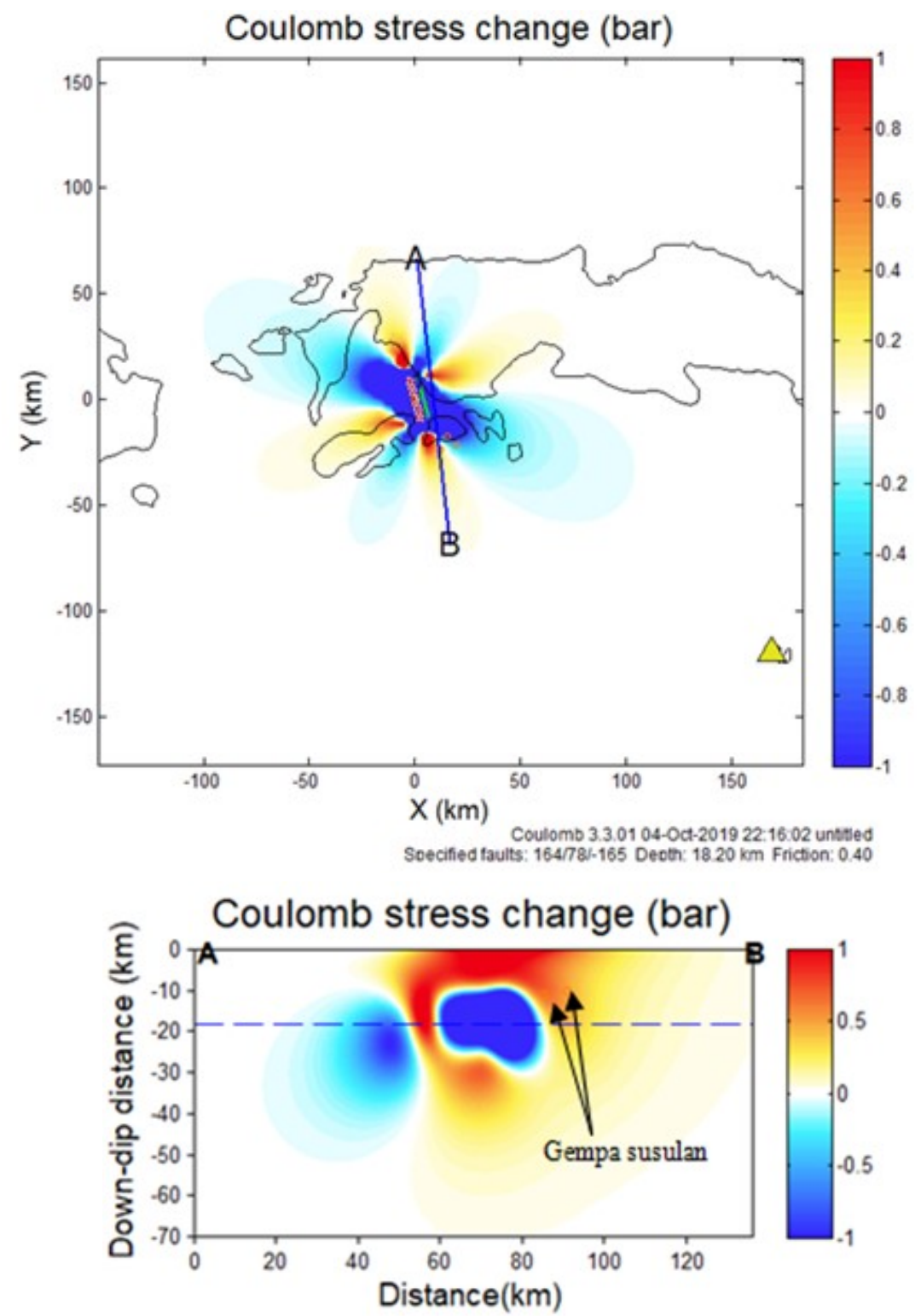

Gambar 4. Cross section perubahan stress yang terjadi akibat gempabumi Kairatu. 
Gambar 4, merupakan cross section yang menampilkan pola penyebaran perubahan stress coulomb batuan secara vertikal berdasarkan kedalaman. Pada gambar terlihat bahwa setelah terjadinya gempabumi utama pada kedalaman sekitar $18 \mathrm{~km}$ berada pada lobus negatif atau dengan kata lain terjadi penurunan stress dengan rentangan harga $-1,0$ sampai $-0,4$ bar. Ini berarti bahwa pada lokasi ini telah terjadi proses relaksasi pada batuan sesaat setelah pelepasan energinya. Kemudian setelah itu, stress batuan diteruskan dan mengalami peningkatan (warna merah/ bernilai positif) ke segala arah pada kedalam 0-30 km sehingga dua gempabumi susulan yang cukup besar pada kedalaman $10 \mathrm{~km}$ diduga dibangkitan oleh gempabumi tama yang terjadi sebelumnya. Berdasarkan penampang di atas, potensi terjadinya gempabumi susulan pada daerah dengan stress positif pada kedalaman sekitar $\leq 70$ $\mathrm{km}$.

Peningkatan stress batuan menyebabkan terjadinya gempabumi susulan yang sangat banyak di area sekitar gempabumi utama. Gempabumi susulan yang banyak tersebut terjadi dalam kurun waktu yang relatif singkat dan berlangsung secara kontinu selama kurang lebih 3 bulan beruturut-turut. Hal ini mengindikasikan bahwa energi yang dilepaskan cukup besar (sekitar 1,0 bar) sudah cukup mampu untuk membangkitkan gempabumi susulan dan berdampak pada peningkatan stress pada batuan secara meluas. Selain itu, kondisi ini menggambarkan bahwa batuan disekitar sesar sumber gempabumi utama cukup rapuh sehingga mudah mengalami pergeseran saat stress didistribusikan. Berdasarkan informasi geologis pada peta Geologi Lembar Ambon Maluku, menunjukkan bahwa Pulau Ambon dan sekitarnya berupa formasi batuan gunung api yang terdiri atas batuan andesit, dasit, breksi dan tuff [12,13]. Jenis batuan yang hampir seragam ini dan masih tergolong batuan beku yang menuju proses tersedimentasi, maka cukup rentan mengalami goncangan saat dikenai energi yang cukup besar lewat distribusi tegangan pada batuan.

\section{Kesimpulan}

Berdasarkan hasil analisis, menunjukkan bahwa gempabumi Kairatu mengalami perubahan stress batuan yang cukup besar dengan perubahan negatif dominan berarah Tenggara - Baratlaut dan Timurlaut -Baratdaya dengan harga sekitar -0,4 sampai -1,0 bar, sedangkan perubahan positif terjadi pada keempat arah yakni Utara, Timur, Selatan dan Barat dengan kisaran harga 0,4 sampai 1,0 bar. Kondisi dengan nilai perubahan stress ini sudah cukup berpotensi membangkitkan (mentrigger) gempabumi susulan dengan kedalam hiposenter berkisar $\leq 70 \mathrm{~km}$. Pengaruhnya pun telah terkonfirmasi dengan terjadinya gempabumi susulan berkisar 2900 lebih selama kurun waktu 3 bulan. 


\section{Referensi}

1. United State Geological Survey (USGS). ( 01 Oktober 2019). Citing Internet sources URL https:// earthquake.usgs.gov/earthquakes/ eventpage/us 700051fd/moment-tensor.

2. Badan Meteorologi, Klimantologi, dan Geofisika (BMKG). ( 01 Oktober 2019). Citing Internet sources URL www.bmkg.go.id

3. G.C.P. King, R.S. Stein, dan J. Lin, "Static Stress Changes and the Triggering of Earthquakes," Bulletin of Seismological Society of America, Vol. 84, No. 3, 935-953, 1994.

4. T. Parsons, S.Y. Robert, Y. Yuji, and H. Ahmad, Static Stress Change From the 8 October, $2005 \mathrm{M}=7,6 \mathrm{Kashmir}$ Earthquake. Geophysical Research Letters, v.33, 2006.

5. M. Miao, and Z. Shou-Biao, Study of The Impact Of Static Coulomb stress Changes Of Megathrust Earthquakes Along Subduction Zone On The Following Aftershocks, Chinese Journal Of Geophysics, Vol.55, No.5, pp. 539-551, 2012.

6. Sianturi, H.L., Mohamad, J.N., Mala, H.U., and Tanesib, J.L. (2018). The Identification of Stress Coulomb Changes in Lombok Earthquakes on August 5 and 9, 2018. In Proceeding The First International Conference and Exhibition on Sciences Technology ICEST 2018, 174-183. Labuan Bajo, Indonesia: International
Conference and Exhibition on Sciences Technology ICEST. Universitas Nusa Cendana.

7. Stein, R.S. (2003). Earthquake conversations: Scientific American, v. 288 , no. 1 , p. $72-79$.

8. Stein, R . S., King, G. C. P., and Lin, J. (1994). Stress Triggering of The $1994 \mathrm{M}=6.7$ Northridge, California, Earthquake by its Predecessors. Science, 265 : 1432-1435.

9. Wells, D. L., dan K. J. Coppersmith. (1994). New empirical relationships among magnitude, rupture length, rupture width, rupture area, and surface displacement: Bulletin of the Seismological Society of America, v. 84, p. 974-1002.

10. Aki, K. dan P. G. Richards. (1980). Quantitative Seismology. New York: W.H. Freeman \& Co., 932 pp

11. King, G. C., Stein, R. S., dan Lin, J. (1994). Static Stress Changes and the Triggering of Earthquakes. Bulletin of Seismological Society of America, v. 84 (3), p. 935-953.

12. Tjokrosapoetro, S., Rusmana, E., Chidan, A. 1993. Peta Geologi Lembar Ambon Maluku. Pusat Penelitian dan Pengembangan Geologi: Bandung.

13. Prabowo, U. N., Amalia, A. F., \& Wiranata, F. E. (2017). Identifikasi Potensi Pergerakan Tanah Pada Lereng Yang Dipicu Gempabumi Berdasarkan Pengukuran Mikrotremor. Wahana Fisika, 2(2), 67-77. 